\title{
MILK AND DAIRY PRODUCT ANALYSES at the Dairy Chemistry Division in Mauritius: an OVervieW
}

\author{
ANALYSE DE LAIT ET DE PRODUITS LAITIERS À \\ la Dairy Chemistry Division À l'île Maurice : un APERÇU
}

\section{ANÁlisis de leChe y de PRODUCtOS lacteos en la Division de Química Láctea EN LAS ISLAS MAURICIO: PANORAMA GENERAL}

\author{
S.A. Neeliah ${ }^{1 *}$ S. Buldewo ${ }^{1}$ B.R. Kureemun ${ }^{1}$
}

\section{Keywords: Dairy cattle - Milk - Chemical composition - Product quality - Microbiology - Mauritius.}

Mots-clés : Bovin laitier - Lait - Composition chimique Qualité des produits - Microbiologie - Maurice.

Palabras clave: Ganado de leche - Leche - Composición química - Calidad del producto - Microbiología Mauricio.

$\mathrm{T}$ he Government of Mauritius has continuously supported the dairy sector. In a 2011 speech, the Acting President pointed out that the implementation of schemes under the Food Security Fund strategic plan yielded satisfactory results such as an increase in milk production by $55 \%$. One institution which has played a key role in boosting the sector is the Dairy Chemistry Division (DCD). DCD forms part of the Agricultural Services which fall under the aegis of the Ministry of Agro-Industry and Food Security (MOAFS). It has been at the forefront of milk testing, constantly innovating with respect to analytical methods and instrumentation use. It has thus evolved from a laboratory that had the responsibility of monitoring the quality of milk in Government dairies and, later on, of locally-produced fresh raw milk under the Pilot Milk Scheme, to an institution providing analytical, advisory and technical services in various fields of food science and technology. From 1999 to 2014, more than 116,000 samples have been tested. The fat and microbial contents, and percentage adulteration with water varied depending on the client. The laboratory was accredited in 2012 by Mauritas, the local accreditation body, for certain microbiological parameters. The aim of this paper was to describe the evolution in DCD activities with a focus on milk testing.

The paper is based on a review of DCD past annual reports and relevant technical documents pertaining to the local milk sector. Food testing started in the 1920s in the Agricultural Services of MOAFS. The main activities were the analysis of morning and evening milk samples from Government dairies for fat, solids non-fat and lactose. The milk was assessed as being of fairly

1. Dairy Chemistry Division, Food Technology Laboratory, Agricultural Services, Ministry of Agro-Industry and Food Security, Reduit, Mauritius.

* Corresponding author

E-mail: moa-dairy-chem@govmu.org good chemical quality. Table I provides a summary of results of analyses of milk collected from Government dairies.

DCD was created in 1973 in line with the Government policy to support the dairy sector. Apart from testing activities DCD has been involved from then on in research, particularly in mastitis surveys, has trained stakeholders and has provided analytical support to stations of the Animal Production Division. Over the years, DCD expanded its services to cover the various stakeholders of the dairy sector. From 1986 until closure of the three Government stations, DCD monitored, weekly, the morning and afternoon milk quality of these stations. DCD also monitored the quality of dairy products manufactured locally by performing chemical and microbiological analyses at the request of major local food manufacturers, importers and micro-entrepreneurs. Technical assistance was provided to other governmental and non-governmental organizations such as the Mauritius Standards Bureau, the Food and Agricultural Research and Extension Institute, the Mauritius Livestock Marketing Cooperative Federation, and the Ministry of Health and Quality of Life. Figure 1 shows the change in the number of samples submitted at DCD from 1999 to 2014. Years 2004 to 2007 were marked by investments in staff training, purchase of new equipment, and culminated with the transfer to new premises. Figure 2 shows the trend (2004-2007) in the monthly average fat content in raw milk submitted by the Agricultural Marketing Board.

In 2006, DCD moved to its new location and added to its usual activities at the Food Technology Laboratory new responsibilities in the fields of microbiological testing, product development, and activities pertaining to the operation of the Codex Contact Point. Following integration of the Food Hygiene Laboratory of the Veterinary Services under the Food Technology Laboratory

\section{Table I}

Fat and total solids content of milk collected from Government dairies in Mauritius

\begin{tabular}{lcc} 
Parameter & $\begin{array}{c}\text { Morning milk } \\
(\mathbf{\%})\end{array}$ & $\begin{array}{c}\text { Evening Milk } \\
\mathbf{( \% )}\end{array}$ \\
\hline Fat & $2.6-4.2$ & $3.1-4.9$ \\
Total solids & $10.9-12.9$ & $11.6-13.8$
\end{tabular}


complex in 2006, the scope of activities has broadened. The different units have been fully equipped with state-of-the-art equipment and the personnel have been regularly trained to meet the growing requirements of the local agro-business sector. Since 2005, there has been a marked decrease in the number of samples tested. The number of samples received at the Microbiology Section has concomitantly increased. The drop in the number of milk samples submitted to DCD coincides with the phasing out of the Pilot Milk Marketing Scheme and the ceasing of milk collection, pasteurization and distribution in May 2008. However, with the incentives provided under the Food Security Fund Strategic Plan (2008-2011), other operators have emerged which explains why DCD has been continuously involved in milk sample testing. The number of submitted samples further decreased with the introduction of fees for provision of analytical services in 2012. However, 404 samples were submitted in 2014 to determine milk chemical characteristics, representing a $31 \%$ increase in the number of samples compared to 2012 ; it is thus relevant to maintain the milk testing facility for stakeholders.

Since 2012 the laboratory has been accredited for six microbiological parameters. It has recently (in 2014) applied for international accreditation for additional parameters with the National Accreditation Bureau of India. In December 2014, the activities under the Pilot Plant were reinitiated with the assistance of the Chinese Agricultural Technical Team. Novel agrofood products, such as cucumber candy, sweet potato and pumpkin cake, are currently being developed.

Accepted 30 April 2015; Online publication June 2015

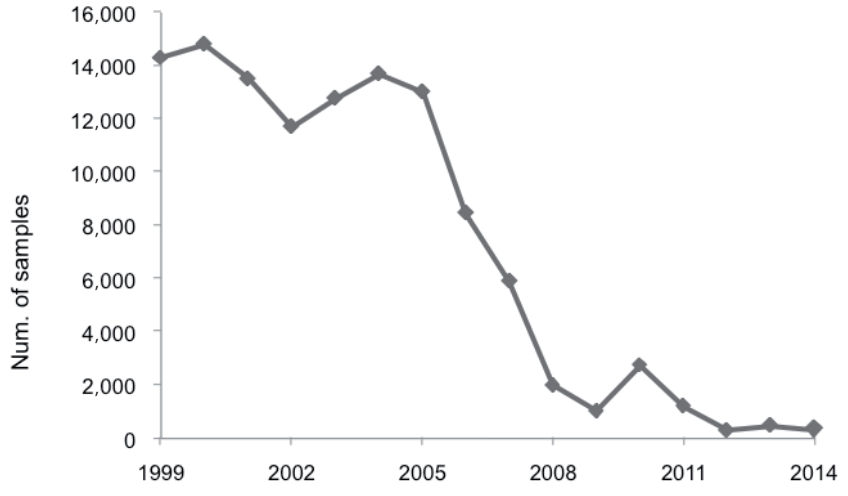

Figure 1: Number of samples tested at the Dairy Chemistry Division in Mauritius (1999-2014).

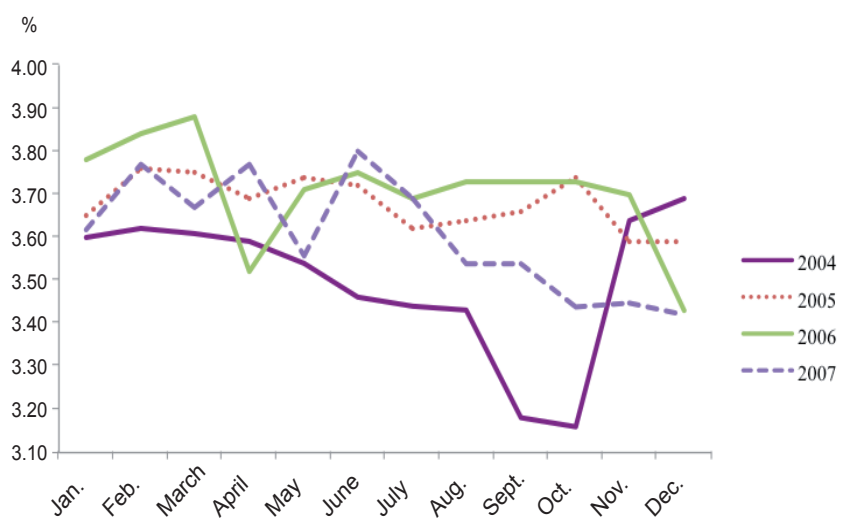

Figure 2: Monthly average fat content in raw milk submitted by the Agricultural Marketing Board in Mauritius (2004-2007). 